\title{
TOP LEVEL RESULTS OF A STUDY OF CZECH HOUSEHOLDS" AWARENESS OF THE FOOD ADVERTISING INDUSTRY'S SELF-REGULATION RELATED TO CHILDREN
}

\author{
Lhotáková, M., Olšanová, K.
}

\begin{abstract}
This paper is primarily focused on analyses of the research undertaken to understand the awareness of food advertising's self-regulation authority (Council for Advertising) and of the Czech Code of Conduct in the context of the growing issue of child obesity. The objective is to find out the perception of food advertising to children and awareness of regulation and industry selfregulation amongst Czech mothers. Our theoretical framework presumes dependence between the awareness levels and selected demographic variables. We conclude several actions to overcome low awareness of the Council of Advertising and its Code of Conduct and to transfer the industry's self-regulation into an efficient and recognized tool of shaping the culture of responsible advertising in the Czech Republic. The conclusions lead towards stronger protection of children. ${ }^{1}$
\end{abstract}

Keywords: advertising targeted to children; regulation of advertising; industry self-regulation JEL classification: M31, M37, M38

\section{Introduction}

This article discusses parental perception of food advertising to children and awareness of the regulation and self-regulation of food advertising to children and of their standpoint regarding stricter regulation of advertising in terms of constraints on unhealthy products (high fat, high sugar). Our previous research has shown that regulation and self-regulation of food advertising to children in the Czech Republic is relatively mild compare to some other developed countries and more importantly self-regulation and regulation are interconnected and strongly influenced by the food industry (Olšanová and Lhotáková, 2014). The causal link between food advertising and childhood obesity is still the subject of discussion, but the opinion prevails that advertising is one of the factors, which co-creates primary values, attitudes and opinions for young people (Grundey, 2007). Advertising is also being considered one of the co-factors leading to the increased level of childhood obesity in the Czech Republic and other developed countries.

The objective of this research article is to find out how Czech mothers perceive food advertising to children and its information content and to evaluate their awareness of regulation and industry self-regulation of food advertising to children as well as of the tools they can use against a food producer breaking the self-regulation rules. Our research is not aimed at contributing to the discussion about the link between food advertising to children and childhood obesity. We follow on the discussion about regulatory models in food advertising to children and aim to conclude specific suggestions on improving the role of self-regulation and legislation authorities in the Czech Republic.

1 An earlier version of this paper has been presented at the 15 th International Joint Conference:

Central and Eastern Europe in the Changing Business Environment, in Prague, May 29, 2015. 


\section{Literature Review}

Obesity has been discussed as a major concern since the World Health Organization published its Report of the Director General in 1998: "Life in the 21st century. A vision for all" emphasizing that "Obesity is increasing, especially in the younger age group. Nutritional problems, especially overconsumption of fats or sugars, are taking their toll" (WHO, 1998). Nowadays, according to WHO, being overweight and obese is ranked as the fifth leading risk for deaths globally (WHO, 2013).

WHO specifies why obesity during childhood creates risk for future adults. An increased $\mathrm{BMI}^{2}$ increases the risk of diseases such as cardiovascular diseases (mainly heart disease and stroke), diabetes, musculoskeletal disorders (osteoarthritis) and some cancers (endometrial, breast, and colon). The obesity of children is, according to $\mathrm{WHO}$, associated with a higher chance of obesity, premature death and disability in adulthood. Additionally, obese children experience breathing difficulties, increased risk of fractures, hypertension, early markers of cardiovascular disease, insulin resistance and psychological effects (WHO, 2013).

Different studies indicate that food advertising to children has a direct link to the development of eating habits which may lead to obesity. For children, advertising creates positive attitudes towards the advertised food products and they are likely unable to understand this persuasion without parental explanation. Their ability to separate advertising content from TV entertainment is not clear. Research exists on proving the effectiveness of self-regulation on children's advertising exposure and in changing household purchasing behaviors (Huang and Yang, 2013). The effect of a ban on fastfood television advertising was also estimated with the result of reducing the number of overweight children aged 3-11 by $18 \%$ and adolescents $12-18$ years by $14 \%$ (Chou et al., 2008). Television food advertising has been linked to children's food preferences, at both brand and category levels, and to both purchasing and consumption habits (Lobstein and Dibb, 2005). Based on the increasing evidence of the link between the advertising and obesity, the pressure for regulation of food advertising to children is growing. Increasingly, it is recognized that voluntarily regulations may not be sufficient and that more transparent enforceable regulations may be required to reduce the pervasiveness of "non-core" food advertising (Kelly et al., 2007). There is a concern that the industry could use self-regulation to avoid more stringent regulation (Hawkes, 2007).

This was confirmed by WHO at the Sixty-third World Health Assembly, where the WHO Member States endorsed a set of recommendations on the marketing of foods and non-alcoholic beverages to children, specifying a set of measures leading to reduction of marketing communication of food targeted to children (WHO, 2010).

\section{Regulation and Self-Regulation of Food Advertising Targeted at Children in the Czech Republic: Current Status}

The food industry's position towards advertising to children is that young people have a right to obtain information from advertising, and therefore, food producers support

$2 \quad$ BMI = Body Mass Index, a measurement of obesity, defined as the weight of an adult human in $\mathrm{kg}$ divided by the square of height in meters squared $\left(\mathrm{kg} / \mathrm{m}^{2}\right)$. According to the WHO definition, it means: $\mathrm{BMI} \geq 25$ overweight, $\mathrm{BMI} \geq 30$ obesity. 
self-regulation rather than statutory regulation resulting from stricter legislation. Selfregulation is defined as a system whereby an industry actively participates in, and is responsible for, its own regulation (Hawkes, 2005). C. Hawkes defines two aspects of self-regulatory systems that are needed to ensure a well-functioning system: (i) the code itself (recognizing that children must be treated differently than adults given their different interpretation of the world) and (ii) effective monitoring and enforcement to ensure industry compliance (Hawkes, 2005).

Self-regulation in the food industry is overseen by the European Advertising Standards Alliance (EASA), which is a non-profit organization based in Brussels. Its main goals are to consolidate the advertising self-regulation in Europe, help European countries create self-regulatory bodies and legislation framework, promote self-regulation in advertising as a more flexible alternative to detailed legislation and coordinate cross-border complaints with the aim of fast resolution (EASA, 2013). Self-regulation exists to protect advertisers (from external regulation) as well as consumers, thereby facilitating the proliferation of advertising - a classic case of 'enlightened self-interest' (Hawkes, 2005).

In EASA, the Czech Republic is represented by the Advertising Council in the Czech Republic (Rada pro reklamu, RPR). The food companies are members of the RPR directly (Danone, Ferrero, Nestlé and a subsidy of McDonalds) or indirectly through the Food Chamber (Potravinárská komora, PK) and the Czech Association of Branded Goods Producers (Český svaz značkových výrobců, ČSZV) (RPR, 2014). RPR's main role is the assessment of complaints regarding advertising in the press, outdoor, direct mail, radio, TV, cinema and the Internet. The complaints with prevailing legal issues are out of its scope as RPR's competency is limited to ethics and voluntary commitments of the industry as stated in the Code of Advertising. RPR can also act based on its own initiative once it realizes that a particular ad may violate certain provisions of the Code of Advertising.

The office of RPR is financed by membership fees, contributions of the food companies or industry associations. It means direct dependence on the member companies and, at the same time, budget limitations resulting in minimum executional staff to deal with selfmonitoring of potentially defective ads. None of the complaints accepted by the RPR in 2004 - 2013 were due to the advertising to children part of the Code (Olšanová, 2013).

As stated above, self-regulation is based on voluntary industry initiative. The formal legislation gives more formal borders for both advertisers and the media. In the Czech Republic, Law No. 40/1995 Coll., as amended (“Advertising Regulation Act”) (Sbírka zákonů ČR, 2013) comprehensively regulates the issue of advertising. It prohibits the advertising of goods or services that are contrary to the law of the Republic; advertising based on subliminal perception, deceptive advertising, hidden advertising, distribution of unsolicited advertising (harassing the recipient or leading to his expenditures) and the advertising that is contrary to good morals. The act also prohibits advertising directed at the audience under eighteen years old, which encourages behavior prejudicial to their health, mental or moral development, advertising of tobacco and alcohol products, as well as sponsorship of sporting events by tobacco manufacturers and reduces the spread of advertising on fire arms and ammunition.

The rules for protection of children and juveniles are set in $\S 2 \mathrm{c}$. With respect to persons under 18 years old, advertising shall not: (i) encourage behavior prejudicial to their health, mental or moral development, recommend to purchase products or services by exploiting their inexperience or credulity, (ii) encourage them to persuade their 
parents or legal guardians or others to purchase the goods or services, (iii) utilize the special confidence they have to their parents or legal guardians or other persons in an inappropriate manner showing them in dangerous situations.

With the adoption of Act no. 40/95, the RPR (in addition to its core business, which is evaluating the acceptability of ads from the ethical point of view) has become the institution from which the supervisory authorities in charge of compliance with the mentioned law (regional trade licensing offices, the Council of the Czech Republic for Radio and Television Broadcasting, Ministry of Health, etc.) require expert advice on the application of the above law in practice. In this context, the Council issued more than 250 expert pieces of advice on compliance with the advertising law to regulate advertising for regional trade offices of the Czech Republic (RPR, 2014).

In our previous research, in which we analyzed relations between institutions involved in regulatory and self-regulatory system in Czech Republic, we have drawn a conclusion that RPR has the power to influence both the self-regulatory as well as regulatory systems through its role as an advisory body to institutions dealing in the regulatory system. Therefore, the whole system is deviated towards an industry that represents the majority of voices in RPR. We also concluded that low involvement of institutions representing consumers and other stakeholders causes low effectiveness of the regulatory and selfregulatory systems in Czech Republic (Olšanová and Lhotáková, 2014).

\section{Methodology}

The research was conducted in January 2015 in cooperation with the research company Stem/Mark, a.s. who was responsible for the sample structure and data collection. A questionnaire consisting of 24 questions was distributed via the Internet to a statistically representative sample of Czech mothers $(n=707)$ selected from the Czech National Panel (on-line panel of 65 thousand respondents). Data collection took place in the week commencing $12^{\text {th }}$ January 2015.

A sample of 707 mothers of children aged $3-18$ years respected the quotas set for the age of the oldest children, education of mother, regionality and size of the city (see the sample's structure in Table 1). The sample is representative in terms of the demographic structure of the Czech population. Fifty-one percent of the respondents have one child, $41 \%$ two children. The majority of the respondents were between $26-45$ years old (52\% 36-45 years, $41 \% 26-35)$. The regionality of the respondents follows the population distribution. Sixteen percent of the mothers have a university degree, $84 \%$ secondary education (44\% high school with a diploma, $40 \%$ high school without a diploma). 
Table 1 | Sample structure

\begin{tabular}{|c|c|c|c|c|c|c|c|c|c|c|c|c|c|c|}
\hline \multicolumn{15}{|c|}{ Sample Structure } \\
\hline & \multicolumn{2}{|c|}{ Total sample } & \multicolumn{12}{|c|}{ Age ofthe respondent } \\
\hline & \multirow[b]{2}{*}{ Total } & \multirow[b]{2}{*}{$\%$} & \multicolumn{3}{|c|}{$18-25$} & \multicolumn{3}{|c|}{$26-35$} & \multicolumn{3}{|c|}{$36-45$} & \multicolumn{3}{|c|}{$46+$} \\
\hline & & & Total & $\%$ r. & $\%$ col & Total & $\%$ r. & $\%$ col. & Total & $\%$ r. & $\%$ col. & Total & $\%$ r. & $\%$ col. \\
\hline \multicolumn{15}{|l|}{ Education } \\
\hline secondary & 284 & 40,2 & 13 & 4,6 & 54,2 & 101 & 35,6 & 34,7 & 162 & 57,0 & 43,9 & 8 & 2,8 & 34,8 \\
\hline secondary w diploma & 313 & 44,3 & 10 & 3,2 & 41,7 & 127 & 40,6 & 43,6 & 168 & 53,7 & 45,5 & 8 & 2,6 & 34,8 \\
\hline university & 110 & 15,6 & 1 & 0,9 & 4,2 & 63 & 57,3 & 21,6 & 39 & 35,5 & 10,6 & 7 & 6,4 & 30,4 \\
\hline \multicolumn{15}{|l|}{ No. of children in the household } \\
\hline 1 child & 362 & 51,2 & 19 & 5,2 & 79,2 & 149 & 41,2 & 51,2 & 176 & 48,6 & 47,7 & 18 & 5,0 & 78,3 \\
\hline $2 \mathrm{c}$ hildren & 295 & 41,7 & 5 & 1,7 & 20,8 & 129 & 43,7 & 44,3 & 156 & 52,9 & 42,3 & 5 & 1,7 & 21,7 \\
\hline $3+$ & 50 & 7,1 & 0 & 0,0 & 0,0 & 13 & 26,0 & 4,5 & 37 & 74,0 & 10,0 & 0 & 0,0 & 0,0 \\
\hline \multicolumn{15}{|l|}{ Age ofthe oldest children } \\
\hline $3-6$ y ears & 204 & 28,9 & 21 & 10,3 & 87,5 & 137 & 67,2 & 47,1 & 44 & 21,6 & 11,9 & 2 & 1,0 & 8,7 \\
\hline $7-11$ years & 230 & 32,5 & 2 & 0,9 & 8,3 & 117 & 50,9 & 40,2 & 107 & 46,5 & 29,0 & 4 & 1,7 & 17,4 \\
\hline $12-15$ years & 160 & 22,6 & 0 & 0,0 & 0,0 & 35 & 21,9 & 12,0 & 118 & 73,8 & 32,0 & 7 & 4,4 & 30,4 \\
\hline 16-18years & 113 & 16,0 & 1 & 0,9 & 4,2 & 2 & 1,8 & 0,7 & 100 & 88,5 & 27,1 & 10 & 8,8 & 43,5 \\
\hline \multicolumn{15}{|l|}{ Size of the municipality } \\
\hline up to 1999 inhabitants & 168 & 23,8 & 7 & 4,2 & 29,2 & 88 & 52,4 & 30,2 & 70 & 41,7 & 19,0 & 3 & 1,8 & 13,0 \\
\hline 2000 - 19,999 inhabitants & 214 & 30,3 & 8 & 3,7 & 33,3 & 90 & 42,1 & 30,9 & 111 & 51,9 & 30,1 & 5 & 2,3 & 21,7 \\
\hline 20,000 - 99,999 inhabitants & 156 & 22,1 & 2 & 1,3 & 8,3 & 49 & 31,4 & 16,8 & 96 & 61,5 & 26,0 & 9 & 5,8 & 39,1 \\
\hline $100,000+$ & 169 & 23,9 & 7 & 4,1 & 29,2 & 64 & 37,9 & 22,0 & 92 & 54,4 & 24,9 & 6 & 3,6 & 26,1 \\
\hline \multicolumn{15}{|l|}{ Regionality } \\
\hline Prague & 85 & 12,0 & 2 & 2,4 & 8,3 & 29 & 34,1 & 10,0 & 51 & 60,0 & 13,8 & 3 & 3,5 & 13,0 \\
\hline Bohemia & 380 & 53,7 & 13 & 3,4 & 54,2 & 163 & 42,9 & 56,0 & 193 & 50,8 & 52,3 & 11 & 2,9 & 47,8 \\
\hline Moravia & 242 & 34,2 & 9 & 3,7 & 37,5 & 99 & 40,9 & 34,0 & 125 & 51,7 & 33,9 & 9 & 3,7 & 39,1 \\
\hline Total & 707 & 100 & 24 & & 100,0 & 291 & & 100,0 & 369 & & 100,0 & 23 & & 100,0 \\
\hline
\end{tabular}

Source: authors based on Stem/ Mark/Czech National Panel data. 


\section{Research Results}

\subsection{Theoretical Framework}

We defined the variables for our theoretical model as follows: the dependent variable is consumer awareness of advertising self-regulation and of the Czech Code of Advertising. Independent variables are defined as age, education and size of municipality. We presume that the there is a positive relation between the age of the mothers, education level and size of municipality of the mothers and the awareness of the Council for Advertising and of the Code itself. We expected the awareness of both to be rather low. Despite this, respondents' structure and size of the sample enabled us to analyze the needed variables and draw conclusions.

\subsection{Research Findings}

Respondents were prompted by a list of institutions which could be in charge of the regulation of food advertising targeted at children (Ministry of Health, Council for Radio and TV broadcasting, health insurances, Council for Advertising, Ministry of Agriculture and Trade, licensing offices). Most of the respondents thought it was the Council for Advertising (RPR) (56\%), followed by Ministry of Health (47\%) and Council for Radio and TV Broadcasting (39\%).

The level of awareness of the existence of RPR was low; only $37.5 \%$ of the respondents claim they are aware of it. They are predominantly 35-45 years old, from Prague or cities above 100 thousand inhabitants with higher education (university or secondary with a diploma) and with higher income. Sixty-two percent of those who are aware of the RPR's existence are also informed about the existence of the Code of Advertising.

Awareness of the Code of Conduct is even lower (22.2\%). Not surprisingly, those who are aware of it are also women $36+$ with higher education, living in bigger cities, predominantly in Prague (see table 2). Nineteen percent of the sample was aware of the fact that they can complain about advertising's content at the Council of Advertising and $4 \%$ of them have already used this option to raise a complaint.

This finding is in line with our previous research which analyzed the complaints received by RPR. In 2002 - 2013, RPR evaluated 738 issues; $21 \%$ of them were found defective in terms of not meeting the rules of self-regulation. On average, it was 62 complaints per year, most of them raised by private persons (Olšanová, 2013; Olšanová and Lhotáková, 2014). None of the complaints were due to potentially breaking the Code in parts related to food advertising to children (Chapter III or specifically Chapter III/3 - Food advertising targeted to children). The self-regulation authority in the United States (CARU) reviews about one thousand commercials each month. They are almost exclusively from internal monitoring. In the U.K. the relevant authority (ASA) deals with around 13 thousand complaints each year; the Canadian ASC deals with more than 1.5 thousand complaints each year. Similar to the Czech Republic, complaints referring to food advertising to children dealt with by the mentioned institutions are less frequent compared to those facing decency, truthfulness and misleading ads (Hawkes, 2005). 


\begin{tabular}{|c|c|c|c|c|}
\hline \multicolumn{5}{|c|}{ Mothers' awareness of RPR and Code of Conduct } \\
\hline & \multicolumn{2}{|c|}{ RPR's awareness } & \multicolumn{2}{|c|}{ Code of Conduct aw. } \\
\hline & $\%$ & index & $\%$ & index \\
\hline \multicolumn{5}{|l|}{ Age } \\
\hline $18-25$ & 20.8 & 55.6 & 16.7 & 75,1 \\
\hline $26-35$ & 30.9 & 82.5 & 22.0 & 99,0 \\
\hline $36-45$ & 42.5 & 113.5 & 22.8 & 102,5 \\
\hline $46+$ & 56.5 & 150.8 & 21.7 & 97,9 \\
\hline \multicolumn{5}{|l|}{ Education } \\
\hline Secondary & 27.5 & 73.3 & 14.8 & 66,6 \\
\hline secondary w diploma & 41.9 & 111.7 & 25.9 & 116,5 \\
\hline University & 50.9 & 135.8 & 30.9 & 139,2 \\
\hline \multicolumn{5}{|l|}{ Size of the municipality } \\
\hline up to 1999 inhabitants & 33.3 & 88.9 & 20.2 & 91,1 \\
\hline 2000 - 19,999 inhabitants & 30.4 & 81.0 & 19.2 & 86,3 \\
\hline 20,000 - 99,999 inhabitants & 41,0 & 109.5 & 24.4 & 109.7 \\
\hline $100,000+$ & 47.3 & 126.3 & 26.0 & 117,2 \\
\hline \multicolumn{5}{|l|}{ Regionality } \\
\hline Prague & 65.9 & 175.8 & 27.1 & 121,9 \\
\hline Bohemia & 34.2 & 91.3 & 23.2 & 104,3 \\
\hline Moravia & 32.6 & 87.1 & 19.0 & 96,7 \\
\hline Total & 37,5 & 100.0 & 22.2 & 100.0 \\
\hline
\end{tabular}

Source: authors

According to the results, the most frequent categories bought by the respondents for their kids, based on advertising ( $N=536$, those who agreed that at least occasionally they do their purchases based on advertising targeted at children) is confectionery (72\%), non-alcoholic sweetened drinks $(61 \%)$, followed by breakfast cereals with high sugar content (33\%), ice cream (32\%) and fast food, hamburgers (11\%) (see Fig. 1).

The team of G. Hastings in their review for the World Health Organization identified 115 studies on the extent and nature of food promotion to children and 90 on its effects. The studies consistently conclude that food promotion is the most prevalent marketing category targeting children and young people. Their content analyses research and found 
that the majority of foods and food products advertised are high in energy, fat, sugar and/ or high salt. The most frequently advertised categories are sugar-sweetened breakfast cereals, soft-drinks, confectionary and savory snacks (Cairns et al., 2009). These findings are in line with what Czech mothers buy under the influence of children who were targeted by food advertising.

\section{Figure 1 | Categories bought by respondents most frequently for their children based on advertising (Q13). $\mathrm{N}=538$ respondents}

Confectionery (chocolate, candies, biscuits)

Non-alcoholic sweetened drinks

Breakfast cereals with high sugar content

Ice creams

Salty snacks (chips, nuts)

Fastfoods (hamburgers)

Sweet spreads high in sugar and fat

(nut spreads)

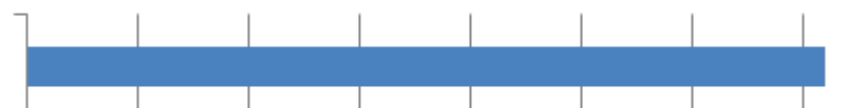

.
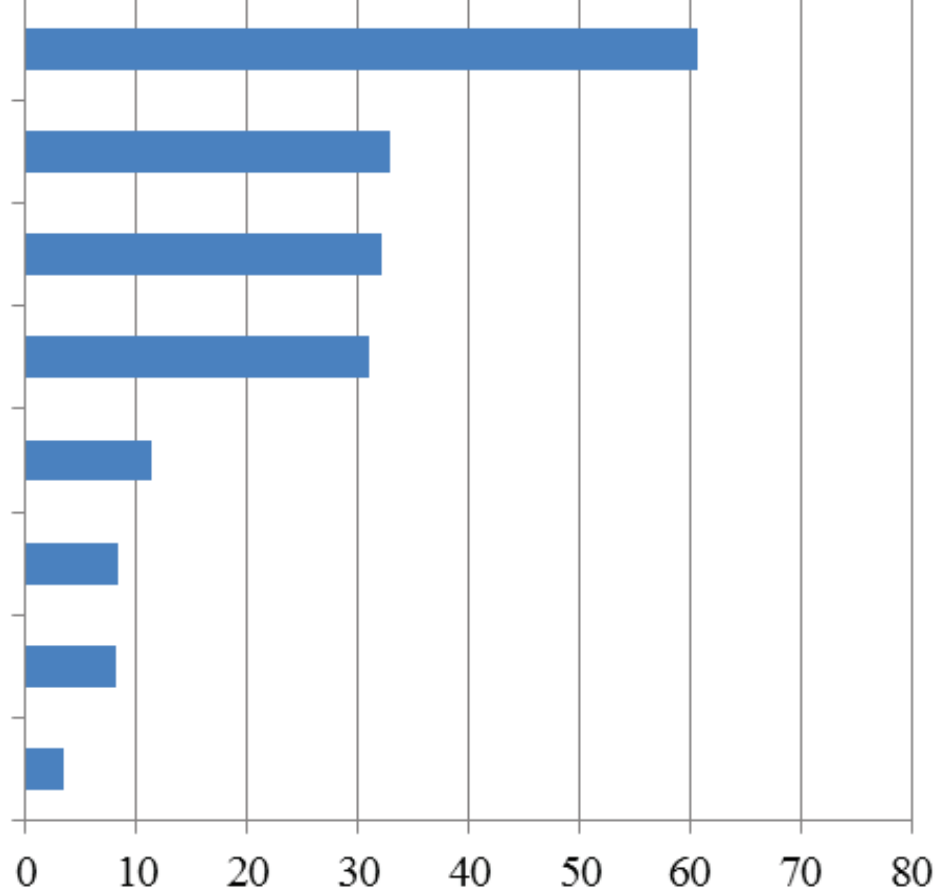

Flavor enhancers (mayonnaise, ketchup, dressing)

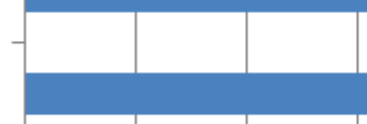

Others

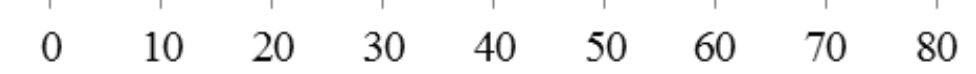

$\%$ of respondents who claimed the category as bought for children based on advertising

Source: authors

We were exploring the level of agreement with the statements corresponding to the wording of the Code of Advertising. As demonstrated in Fig.2, respondents tend to disagree (on a 4 point scale) that the food ads targeted to children don't promote products high in sugar, salt and fat (mean 3.0); the advertisements promote healthy and balanced diets (3.0); contain detailed description and characteristics of the product presented (3.0); inform about what is healthy for children and what is not (2.9) and promote a healthy and active lifestyle (2.9). This demonstrates that Czech mothers are rather rational in terms of their expectancy of the positive/negative impacts of food advertising.

The level of agreement with the statement that the food and drinks promoted in these ads are presented as being consumed in reasonable amounts was rated in the middle (mean 2.5). They tend to agree with the negative statements (The ads encourage children to persuade parents or other adults to buy them the advertised products - mean 1.7; the advertising is sometimes misleading - mean 1.8; and that the advertisements lead children 
to thinking that if they do not have the advertised products they will become in any way inferior to other children (mean 2.1).

The majority of the respondents claim that the food advertising targeted to children should be more regulated in terms of limiting ads for food high in fat, sugar or other unhealthy food $(83 \%)$. Only $6 \%$ of them disagree with stronger regulation. More than half of the sample claimed agreement with the statement that advertising serves as a good guide when a new product appears on the market (53\% agreed or rather agreed). They would like to be backed-up by stronger regulation of advertising from the authorities, while they appreciate the informational role of the advertising, especially in the new product launch phase.

\section{Figure 2 | Level of agreements with the statements (means), $\mathbf{N}=707$ respondents}

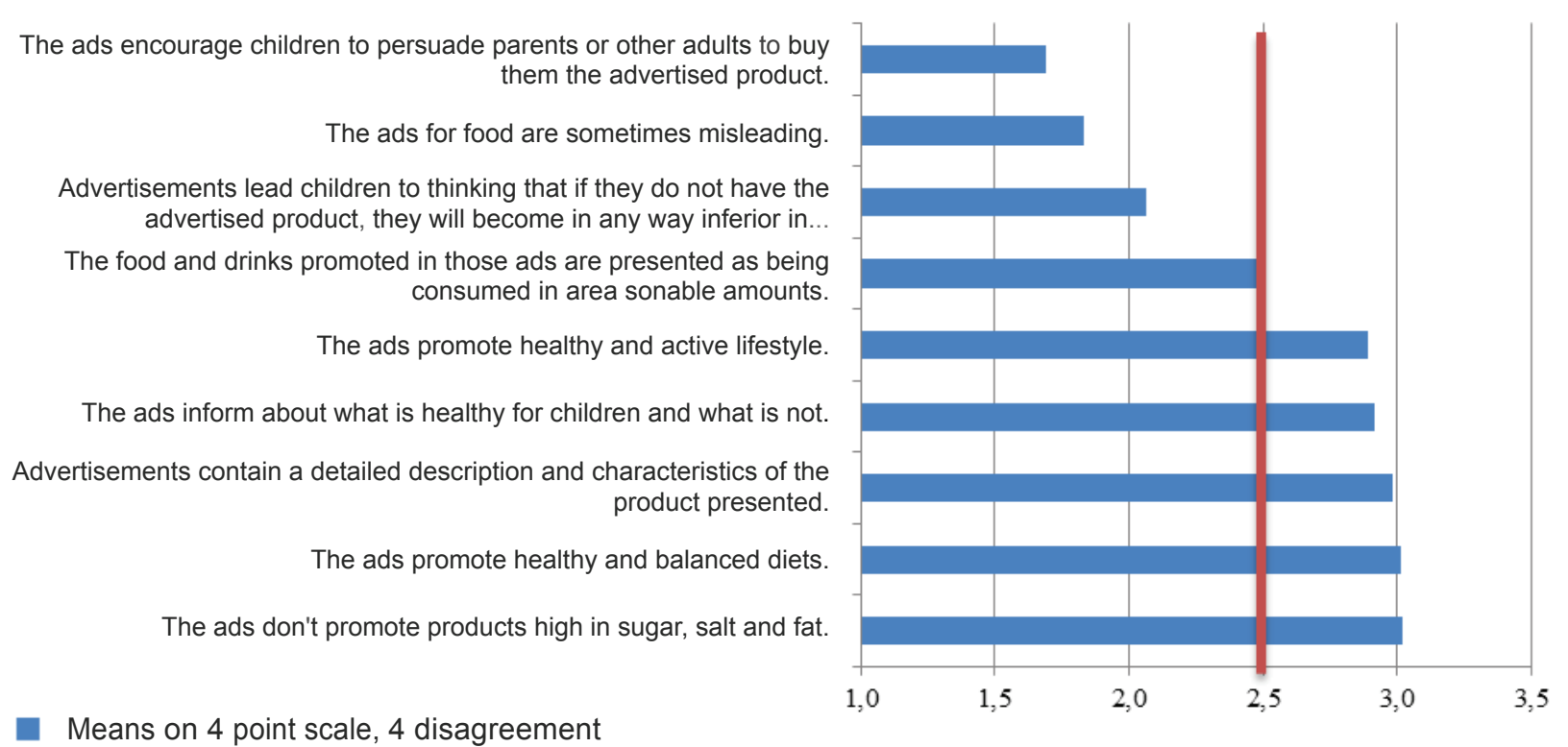

Source: authors

In Figure 3, we summarize the general approach of the respondents to the advertising. They tend to disagree that sometimes the advertising is useful for the consumers (mean 2.6). The disturbing role of advertising for the majority of the respondents is expressed by level of agreement with the statements that the ads force people to buy products they would not buy without them (2.0); and that despite the fact that they know that ads always slightly exaggerate, they tend to be influenced when purchasing advertised product (2.4). They agree that even high quality products need advertising (2.1). On the contrary, they do not believe that advertising is useful for the consumers.

That advertising is a source of information when launching new products is accepted by the majority of the respondents (53\% agree or rather agree, mean 2.5$)$. The agreement level is higher in the group of respondents who admit often purchasing food for children based on advertising (95\%, mean 1.5; resp. 2.4 (often; sometimes purchasing based on advertising)). 
Figure 3 | Level of agreements with the statements (means), $N=707$ respondents

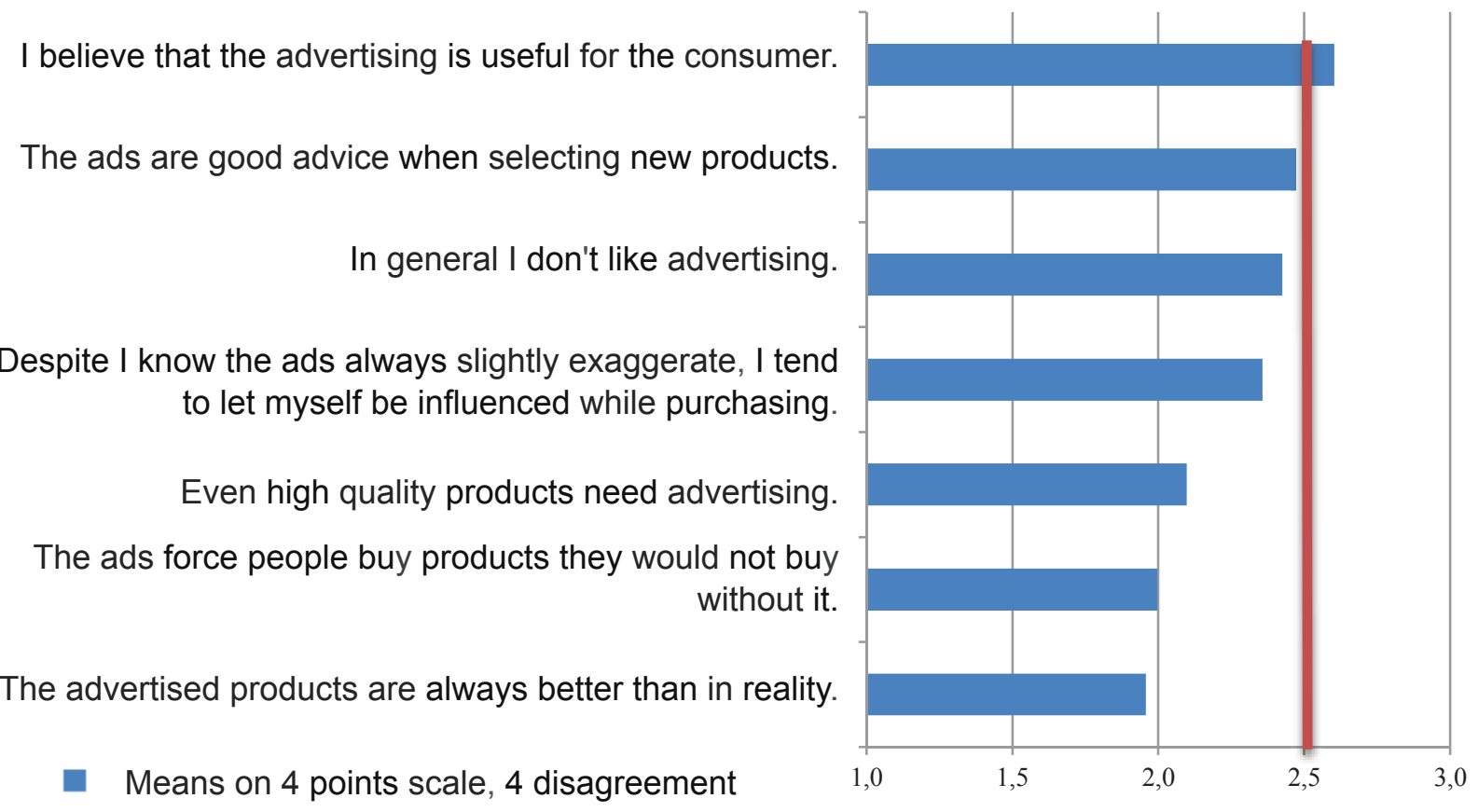

Source: authors

\section{Conclusion}

Our previous research has indicated that the current system of regulation and self-regulation of food advertising to children in the Czech Republic is not entirely effective. The low amount of complaints related to food advertising targeted at children related to specific parts of the Code of Advertising (Chapter III, III/3) is not a result of strict implementation of the rules and best practices of the advertising or food industry but more likely a result of the low involvement of the parents and other stakeholders in the system (self-monitoring of RPR, Ministry of Health). Consumers tend to include the Ministry of Health into the list of organizations responsible for advertising regulation.

Our research indicates low awareness of both the basic building blocks of the industry's self-regulation in the Czech Republic, e.g. of the Council of Advertising (37.5\%) and of the Code of Conduct (22.2\%). As expected, the awareness of the selfregulation process grows with higher education, larger sizes of the municipality and age of mothers. The results of our research show that stronger regulation of food advertising targeted to children is supported by a strong majority of the respondents. Balancing the system would need building awareness of the self-regulation authority in the Czech Republic by raising visibility of its role and by building monitoring of food advertising. This would require changes in financing of the RPR and also changes in the structure of the arbitration commission or more significant changes in the decision making process at RPR. In Canada, as an example, complaints are dealt with by the consumer committee with representatives from the industry and public sector (though still also criticized for being too industry friendly) (Hawkes, 2005).

Our research has indicated that mothers consider advertising in general as a helpful source of information about new products $(53.2 \%)$ but are much more critical towards food advertising to children. Eighty-three percent of them think that food advertising is 
sometimes misleading. Most importantly, $81 \%$ of mothers claim that food advertising targeted to children does not support healthy and balanced eating habits and $70 \%$ respondents claimed that the advertising leads children to thinking that if they do not have the advertised product they will become in some way inferior in relation to other children. This indirectly confirms that, according to our research, a majority of food advertising targeted to children does not comply with the statements that should be valid for advertising targeted at children according to the Code of Advertising.

There are three specific implications based on the presented data. The regulation of food advertising targeted to children should be stricter. If this is to be without a strong regulatory framework, then the role of the RPR needs to be clarified in terms of its financing, visibility and self-monitoring activities. Parents should be informed about the key parts of the Code of Advertising, of their rights and role in helping the industry regulator to fulfill its role.

Limitations of the methodology of our research should be mentioned. The Czech National Panel is a joint project of research agencies NMS Market Research, Mediaresearch and Stemmark. It has over 65000 respondents in the structure similar to the Internet population. The advantages of the interviews with on-line respondents selected from the panel based on given quotas is the speed (as the data collection is significantly faster than traditional modes), elimination of interviewer error, quality control of the panel (managed by the research agencies) and cost effectiveness. The main disadvantages of the method are limits in Internet penetration and the possibility that the target audience is not "Internet educated". Certain demographics and niche sectors may be particularly expensive and/or hard to reach online, which is not a valid limitation of this research.

These findings were based on key results of the research. We will conduct additional analyses to identify variables explaining the awareness levels. In our future work, we will stay focused on regulation of the marketing targeted at children.

\section{References}

Cairns, G., Angus, K., \& Hastings, G. (2009). The extent, nature and effects of food promotion to children: a review of the evidence to December 2008. Geneva: World Health Organization.

Chou, S.-Y., Rashad, I., \& Grossman, M. (2008). Fast-food restaurant advertising on television and its influence on childhood obesity. Journal of Law and Economics, 51 (4), 599-618.

EASA (2013). Web European Advertising Standards Alliance. Retrieved Retrieved April 18, 2014 from http://www.easa-alliance.org.

Grundey, D. (2007). Global Marketing Ethics: Social and Emotional-Psychological Issues in Advertising to Children. Transformations in Business and Economics, 6(2).

Hawkes, C. (2005). Self-regulation of food advertising: what it can, could and cannot do to discourage unhealthy eating habits among children. Nutrition Bulletin, 30(4), 374-382.

Hawkes, C. (2007). Regulating Food Marketing to Young People Worldwide: Trends and Policy Drivers. American Journal of Public Health, 97(11), 1962 - 1973.

Huang, R., \& Yang, M. (2013). Buy what is advertised on television? Evidence from bans on child-directed food advertising. Journal of Public Policy \& Marketing, 32(2), 207-222.

Kelly, B., Smith, B., King, L., Flood, V., \& Bauman, A. (2007). Television food advertising to children: the extent and nature of exposure. Public Health Nutrition, 10(11), 1234-1240.

Lhotáková, M., \& Olšanová, K. (2014). Effectiveness of the advertising targeted to children regulation and self-regulation with focus on food industry. Acta Oeconomica Pragensia, 2014(5), 54-70. 
Lobstein, T., \& Dibb, S. (2005). Evidence of a possible link between obesogenic food advertising and child overweight. Obesity reviews, 6(3), 203-208.

OECD (2010). Obesity and the economics of prevention: Fit not fat. Retrieved April 18, 2014, from www.oecd.org: http://www.oecd.org/els/health-systems/46044572.pdf.

Olšanová, K. (2013). Food Marketing to Children - Review of the issue for further exploration. Central European Business Review, 2(3), pp. 43 - 50.

Owen, L., Lewis, C., Auty, S., \& Buijzen, M. (2013). Is children's understanding of nontraditional advertising comparable to their understanding of television advertising? Journal of Public Policy \& Marketing, 32(2), 195-206.

Quilliam, E. T., \& Rifon, N. J. (2009). Trick or treat: Children, advertising and social responsibility. American Academy of Advertising Conference Proceedings (pp. 30 - 32). American Academy of Advertising.

RPR (2014). Rada pro reklamu. Retrieved October 20 2014, from http://www.rpr.cz.

Rada pro rozhlasové a televizní vysílání (2014). Rada pro rozhlasové a televizní vysílání. Retrieved April 3, 2014, from http://www.rrtv.cz/cz/static/o-rade/priority-rady/index.htm.

RRTV (2014). Děti a média. Retrieved April 29, 2014, from http://www.detiamedia.cz/art/1443/ problematika-reklamy-na-nezdrave-potraviny.htm.

Sbírka zákonů ČR (2013). Zákony - on-line. Retrieved May 20, 2013, from http://zakony-online. $\mathrm{Cz} / ? \mathrm{~s} 171 \& \mathrm{q} 171=$ all.

United Nations (2013). The Convention on the Rights of the Child. Retrieved May 30, 2013, from http://treaties.un.org/doc/source/training/regional/2009/13-17October-2009/humanrights.ppt.

WHO (2010). Marketing Food to Children. Retrieved January 19, 1014, from http://www.who.int/ dietphysicalactivity/marketing-food-to-children/en/.

WHO (2013). WHO: Obesity and overweight. Retrieved May 27, 2013 from http://www.who.int/ mediacentre/factsheets/fs311/en/index.html.

World Obesity (2013). World Obesity (formerly IASO) History. Retrieved April 17, 2013, from http://www.worldobesity.org/who-we-are/history/.

Zimmerman, F. J., \& Bell, J. F. (2010). Associations of television content type and obesity in children. American Journal of Public Health, 100(2), 334-40.

\section{Authors}

Ing. Markéta Lhotáková, Ph.D.

Department of International Business

Faculty of International Relations

Prague, Czech Republic

marketa.Ihotakova@vse.cz

\section{Ing. Květa Olšanová}

Department of International Business

Faculty of International Relations

Prague, Czech Republic

kveta.olsanova@vse.cz

This article was prepared with support of the University of Economics, Prague and Stemmark, a.s. 